\title{
Petroleum Engineering Education in NEFU, Yakutia
}

\author{
Albina A. Goldman* \\ Mirny Polytechnic Institute (branch) \\ of Ammosov North-Eastern Federal University (NEFU) \\ 5/1 Tikhonova Str., Mirny, Sakha (Yakutia), 678170, Russian
}

Received 27.05.2015, received in revised form 01.06.2015, accepted 12.07.2015

The article deals with petroleum engineering highereducation in the Mirny Polytechnic Institute (branch) of NEFU and the oil and gas industry in the Sakha Republic (Yakutia), Russia. Yakutia possesses the largest oil and gas deposits in the Russian Far East. The discovery and exploitation of petroliferous deposits resulted in the opening of Petroleum Engineering major in the Mirny Polytechnic institute of NEFU. Specializing in the field of petroleum engineering, the Mirny Polytechnic Institute's portfolio of programmes has been specifically tailored to meet the demands of the oil and gas employment market in the area. Today, the Mirny Polytechnic Institute is the prominent educational, scientific and cultural centre of Western Yakutia, always at the forefront of innovative education and research.

Keywords: Mirny Polytechnic Institute, petroleum engineering, industrial enterprises, oil and gas, education.

DOI: 10.17516/1997-1370-2015-8-8-1551-1559.

Research area: pedagogy.

\section{Introduction}

Sakha Republic (Yakutia) is the largest region of the Russian Federation. It is known for its rich natural resources. Famous diamond and gold deposits are located here. The sustained development of Yakutia has a great importance for the Russian Far East. The main attractions for investors in the republic are the natural resources potential and the geographical position. Today Yakutia possesses the largest oil and gas deposits in the Russia Far East surpassing even the Sakhalinskaya Oblast.

As of January 1, 2015, Yakutia's State Register of Mineral Reserves included 59 types of mineral and hydrocarbon deposits located in more than 2,000 fields. 455 of the deposits are widespread mineral deposits. Also on the territory of Yakutia, more than 16,000 emersions of different kinds of mineral and hydrocarbon crudes were discovered, as the First Deputy Chairman of the Sakha Republic State Committee for Geology and the Use of Subsurface Resources Vitaliy Kalashnikov reported at a meeting with ROSGEOLOGIYA on May 28, 2015.

All in all, 21 license holders are operating in 60 license blocks on the territory of Yakutia. The most prominent of them are GAZPROM, SURGUTNEFTEGAZ,

(C) Siberian Federal University. All rights reserved

* Corresponding author E-mail address: mptisvfu@mail.ru 


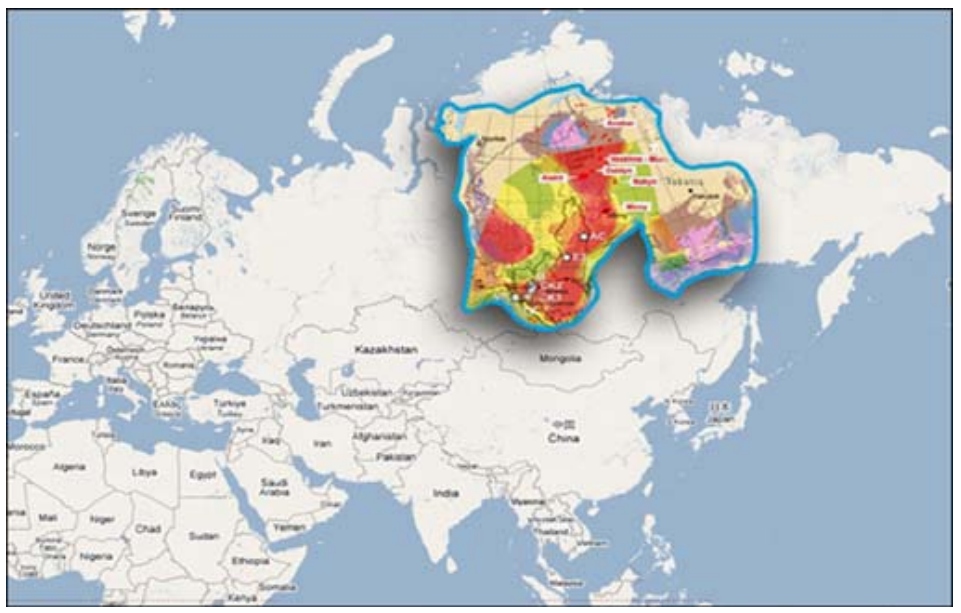

SAKHATRANSNEFTEGAZ, Yakut Fuel Energy Co., TAASURYAKH NEFTEGAZODOBYCHA, GAZPROMNEFT ANGARA, ROSNEFTEGAZ, IRKUTSK Oil Company, and others.

Yakutia's State Register of Mineral Reserves includes 47 diamond deposits, 16 of them primary and 31 alluvial deposits. The capacity of explored balance reserves at the present production level and reclamation is more than 25 years.

The state of the gold mining industry was estimated by Vitaliy Kalashnikov as rich enough to keep the annual production up to 25 tons per year. He added that the crude potential of the deposits is capable of keeping this level for a long period of time provided that appropriate investment in geological exploration is made [1].

Petroliferous territories cover all western part of the republic. The list of oil and gas deposits of the Sakha Republic, Russian Federation, includes 34 fields. Gas prospecting has reached 2.3 billion cubic metres, and oil development 300 billion tons. In the two neighbouring regions of the Republic Lensk and Mirny - the largest oil, gas and condensate fields are located: Chayandinskoye, Talakanskoye, Srednebotuobinskoye and TaasYurekhskoye. These fields are included in the federal oil and gas transportation project "Strength of Siberia". The main investors of the project are SUGRUTNEFTEGAZ, GAZPROM, ROSNEFT, ALROSA GAS, TAASURYAKH NEFTEGAZODOBYCHA and others.

To meet the needs for specialists in the field of oil and gas, the government of the Republic issued the opening of the Petroleum Engineering Department in the Mirny Polytechnic Institute (branch) of Yakut State University (today's NEFU) in 2008.

In 2012, the first petroleum engineers graduated from the Institute. Nowadays, many of them are successfully working at leading industrial oil and gas enterprises.

\section{Oil and Gas Production in the Sakha Republic}

The Sakha Republic of the Russian Federation possesses 34 deposits of natural gas (2716 billion cubic metres) and crude oil (546 billion tons). Inferred resources of the Republic are estimated at 12 trillion cubic metres of gas and 546 million tons of oil. At the moment, only $20 \%$ of the inferred resources of the Republic have been exploited [2].

Table 1 illustrates main indicators of oil and gas mining in Yakutia from 2008-2012. One can observe the steady growth of oil and gas extraction in the Sakha Republic during the given period. 
Table 1. Main indicators of oil and gas industry in Sakha republic in 2008-2012

\begin{tabular}{|c|c|c|c|c|c|c|}
\hline & 2008 & 2009 & 2010 & 2011 & 2012 & $2008-2012$ \\
\hline \multicolumn{7}{|c|}{ Oil extraction } \\
\hline thousand tons & 674,6 & 1846,7 & 3426,2 & 5513,8 & 6713,7 & 18175,0 \\
\hline \multicolumn{7}{|c|}{ Natural gas extraction } \\
\hline billion $\mathrm{m}^{3}$ & 1775,9 & 1893,4 & 1906,6 & 1884,5 & 1980,5 & 9440,9 \\
\hline \multicolumn{7}{|c|}{ Gas condensate extraction } \\
\hline thousand tons & 84,4 & 89,1 & 92,1 & 89,0 & 93,6 & 448,2 \\
\hline \multicolumn{7}{|c|}{ Motor fuel production } \\
\hline thousand tons & 5,2 & 18,8 & 36,8 & 44,5 & 28,5 & 133,8 \\
\hline
\end{tabular}

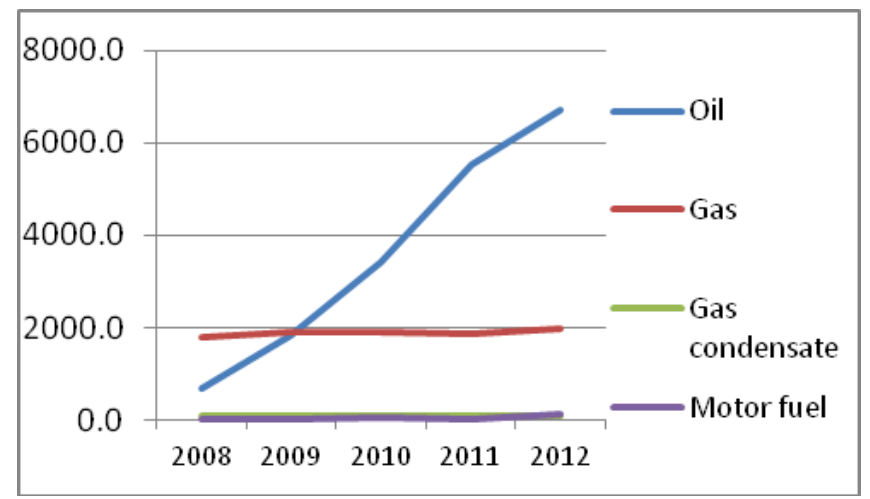

Fig. 1. The growth of oil and gas industry in the republic of Sakha in 2008-2012

So petroleum engineering has become one of the most intensely developing spheres of industry in the Republic.

The crucial year in the development of the oil and gas industry was 2004, when one of the most prominent Russian oil and gas companies SURGUTNEFTEGAZ OJSC became a license holder in Yakutia. The entrance of this company resulted in the rapid growth of the oil and gas industry. As you can see in the Fig. 1, oil extraction grew intensely in 2008-2012. The lion's share of this volume belongs to the Talakanskoye field.

In 2009 the completion and commissioning of the first stage of the pipeline system "East Siberia and Pacific Ocean" signified one step up in the oil production of the Republic. In previous years it was limited to the extraction of oil only for housing and utility services. Following the commissioning of the pipeline system, oil companies now have the opportunity to arrange oil delivery beyond the Republic.

Severo-Talakanskoye, VostochnoAlinskoye, Peleduyskoye and YuzhnoTalakanskoye fields were discovered by SURGUTNEFTEGAZ OJSC in the Sakha Republic during the period of 2007-2011. Talakanskoye, Alinskoye, Severo-Talakanskoye and Vostochno-Alinskoye fields were joined to the "East Siberia and Pacific Ocean" pipeline system and put into operation and maintenance. In Talakanskoye field, a pilot operation of a bitumen plant is being held at the moment.

The five largest fields of the Republic including the Chayandinskoye field, the central 
unit of Yakutian gas production - passed to OAO GAZPROM.

October 2012, the top management of OAO GAZPROM took a final decision for an investment in the Chayandinskoye project and the "Yakutia - Khabarovsk - Vladivostok" gas pipeline construction. The operation of GAZPROM in Yakutia is a real influence for the social and economic development of the region. Particularly the construction of this gas pipeline will lead to the development of gasification in the Republic. The gas pipeline "Yakutia Khabarovsk -Vladivostok" will go through the southern regions of Yakutia; and its location is specifically designed to provide gas to as many settlements as possible.

The immanent resource potential of the Russian East and the foundation of a series of large gas production centres, along with the construction of transportation links, will together launch a new phase in the exportation of Russian gas to the Asia-Pacific Region.

The development of Chayandinskoye field and the commissioning of the main gas pipeline "Yakutia-Khabarovsk-Vladivostok" have given Russia an opportunity to discover new horizons for gas exportation. As a result, negotiations have begun with China.

May 21, 2014, Russia and China signed a 30-year, \$400bn (£237bn) deal for GAZPROM to deliver Russian gas to China. The contract, which is to provide 38 billion cubic metres of gas each year, was signed by the state-owned gas companies GAZPROM and CNPC (China National Petroleum Corporation) in the presence of the countries' leaders, Vladimir Putin and Xi Jinping [3].

The foundation of the Yakutian gas production centre will increase local employment. Over 3,000 local petroleum engineers will be in demand to serve GAZPROM's pipeline and plants.

\section{Petroleum Engineering Education in Mirny}

Rapid development of the oil and gas complex in Yakutia brought to an acute demand for local, highly-qualified petroleum engineers.

The core of the Yakutian oil and gas complex is in western Yakutia, as the majority of the positive reserves of hydrocarbon crude are located in the western and south-western parts of the Republic. The largest oil and gas fields Chayandinskoye, Talakanskoye and SredneBotuobinskoye are situated in western Yakutia (Fig. 2). All of them are oil, gas and condensate fields with the prevalence of a certain kind of petroleum commodities. Moreover, this part of Yakutia possesses a number of large deposits which have not yet been allocated to any producer companies.

The Mirny Polytechnic Institute (branch) of the Ammosov North-Eastern Federal University is located in the industrial centre of western Yakutia, Mirny city, the heart of the diamond mining centre of Russia and the centre of the oil and gas industry of the Republic. It was founded in 1994 by a decision of Mikhail E. Nikolaev, the first President of the Sakha Republic who proclaimed this education policy to be a priority in the development of the Republic for the decades hence. It was intended to provide the ALROSA Company with needed specialists [4].

ALROSA is the world's leading diamond mining company, accounting for more than $25 \%$ of global diamond production. It accounts for $95 \%$ of Russia's overall diamond output. The headquarters of ALROSA and the largest highgrade diamond deposits are situated in the Mirny region, Sakha Republic [5].

Since its foundation the Institute has trained 2,409 specialists, including 976 diamond mining engineers for ALROSA. 


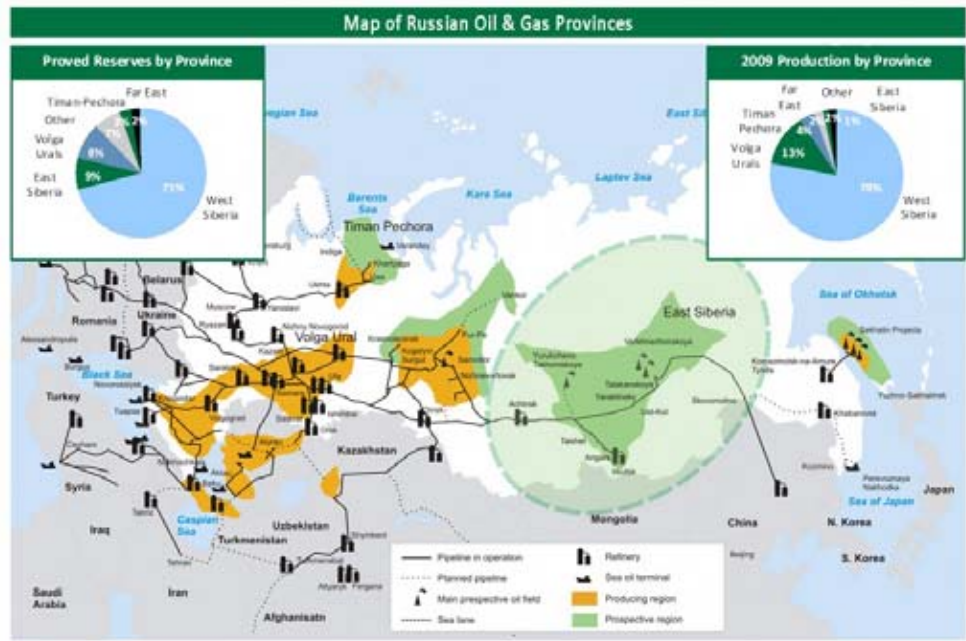

Fig. 2. Russian Oil and Gas Provinces

Today, the Mirny Polytechnic Institute is the prominent educational, scientific and cultural centre of western Yakutia, always at the forefront of innovative education and research.

The Institute's fully equipped campus provides a challenging while supportive learning environment for its students. Our facilities include student accommodation in two comfortable dormitories with internet access, reading rooms, gym and cafeteria; high quality engineering laboratories, multi-purpose auditoriums with video-conferencing facilities, a language studies centre with facilities for a virtual learning environment, two specifically equipped language laboratories, and a modern gym with a range of athletic facilities.

Our Institute trains mining engineering students for the Specialist Degree in three majors:

- Underground Mining of Mineral Deposits

- Electrical Engineering and Automation in Mining

- Mining Machines and Equipment

And five majors for the Bachelor's Degree:
- Petroleum Engineering

- Mathematics

- Applied Mathematics and Computer Science

- Philology (the English language and literature)

- Economics

The rapid development of the oil and gas industry and the integration of prominent oil and gas enterprises in Yakutia motivated the former President of the Sakha Republic Vyacheslav Shtyrov to issue the opening of the Petroleum Engineering major in the Mirny Polytechnic Institute in 2008. This was a pioneering project in Yakutia.

Specializing in the field of petroleum engineering, the Mirny Polytechnic Institute's portfolio of programmes has been specifically tailored to match the demands of the oil and gas employment market in the region, giving our students the best possible career advancement opportunities.

The petroleum engineering programmes offer specialisations in the operation and maintenance of oil fields; and the operation and maintenance of gas, gas condensate and 
subsurface fields. The Institute provides highquality education through modern laboratory facilities as well as actual practice in the working fields within the conditions of permafrost. The curriculum is intended to prepare graduates to operate the latest equipment and to follow a research approach to their work [6].

The academic staff of the Oil and Gas Department is mostly represented by graduates of the Gubkin Russian State University of Oil and Gas. All of them hold Candidate of Science and Master's Degrees in Petroleum Engineering.

The rapid development of the oil and gas sector requires up-to-date education technologies. The following petroleum engineering laboratories are being equipped in the Institute:

- Laboratory of Petrophysics and Core Examination enables the students to analyze oil and gas field cores according to their physical, mechanical and chemical properties.

- Laboratory and Field Testing Site of Oil and Gas Production Equipment requires wells with full scale oil and gas equipment: an electrical centrifugal pump unit, a deep well pump, screw pulsers. This equipment is used both in the learning process and research work.

- Laboratory of Oil and Gas Geology imitates oil and gas reservoirs. Geological surveys of virtual production fields can be carried out through high resolution graphics in this laboratory.

- Laboratory of Oil and Gas Chemistry and Process Liquids carries out laboratory works for the Chemistry and Oil and Gas Chemistry courses. The laboratory is geared for learning methods and instruments for chemical analysis. The students can hold chemical experiments; get acquainted with chemical substances and their alterations, and analyze oil and oil products according to certain requirements.

- Laboratory of Oil and Gas Wells Exploitation is provided with state-ofthe-art equipment for oil and gas wells work analysis in different operation conditions.

- Gas-hydrodynamic and Field Development Simulation Class-Laboratory deals with research work in geological and hydrodynamic field development and design, 3D models construction and project data.

The students of the Petroleum Engineering Department take part in numerous contests, grant programmes and scientific conferences.

The most prominent of them are:

Nyurgun Alexeev - 2012 graduate; the winner of North2North Student Mobility Program grant of the University of the Arctic, took a course in Stockholm University in 20112012. In 2013, he undertook scientific research of heavy oil recovery at the Enhanced Oil Recovery Institute in China's University of Petroleum. In 2014, he received an internship for the Master's final work on multi-lateral wells at the the Field Operation Department at Total EP, Russia. In 2014, he obtained a Master's Degree in Petroleum Engineering (Gubkin Russian State University of Oil and Gas). At present, he works at SEIC Company as a Graduate Wells Engineer.

Victor Popov - 2012 graduate; the winner of the 66th International Youth Scientific Conference “Oil and Gas - 2012”, Moscow. In 2014, he earned the Master's Degree (Gubkin Russian State University of Oil and Gas). At present, he works at Baker Hughes oil and gas company.

Aytal Struchkov - 4th year student; the winner of Hokkaido Short Term Education Program grant, studied in Japan from September 2014 to January 2015; the winner of The $8^{\text {th }}$ All- 
Russian Herzen Youth Forum 'My Initiative in Education' (St. Petersburg); bronze medalist of Open International Students' Internet Olympiad on History.

Pavel Dobrolyubov - 4th year student; the winner of the 6th and 8th All-Russian Herzen Youth Forum 'My Initiative in Education' (St. Petersburg) in 2013; a participant in the London International Youth Science Forum, 2014; the winner of the Russian Far Eastern and Moscow International UN Models; the winner of a Program Grant for Student Leaders on Global Environmental Issues at the Study of the United States Institutes (SUSI); participant of the London International Youth Science forum; bronze medalist of the Open International Students' Internet Olympiad on Ecology and Economics.

The results of the scientific activity of our students are exhibited at different conferences and forums including the London International Youth Science Forum, the International Youth Scientific "Oil and Gas" Conference, the International Scientific Conference on "Student and Technological Progress", the All-Russia Research and Practice Conference on "Youth and Technological Progress in the Modern World", the All-Russia Conference on "The challenges of the development of hydrocarbonaceous and ore mineral resources deposits", the All-Russia Scientific Forum of Federal Universities, the Annual Students' Scientific Forum, and many others.

Undergraduate students apply the results of their scientific activity to their course and diploma papers. They also take part in various sponsored projects together with their scientific supervisors.

Due to the convenient geographical position of the Institute in Mirny - the centre of oil and gas province-we hold practical classes in the working oil and gas fields. The institute has close ties with industrial enterprises GAZPROM, ROSNEFT, SURGUTNEFTEGAZ, ALROSA GAS, TAASURYAKH NEFTEGAZODOBYCHA, IRELYAKHNEFT, and others.

Students can analyze real oil and gas equipment and apparatus indicators to make calculations. This experience will help them to solve similar tasks in their future professions. Our final year individual student projects are designed to be relevant to the needs of the local oil and gas mining industry; many are carried out in collaboration with companies, which benefit from the student's innovative thinking while providing them with experience of reallife challenges.

We also take part in public hearings of industrial enterprises and monitor environmentally safe technologies for the extraction and processing of natural resources in the Mirny region [7].

The Institute collaborates with leading oil and gas universities of Russia in research programmes and on-line distance learning: Gubkin Russian State University of Oil and Gas, Tyumen State Oil and Gas University, National University of Science and Technology (Moscow), National Mineral Resources University (Saint-Petersburg). We conduct joint scientific and analytical research on the following issues:

- Construction of problem-oriented simulators of hydrodynamic modelling of oil and gas condensate fields;

- Simulation of polyphase hydrocarbonaceous systems filtration;

- Construction of subsurface storage of gas and gas condensate in permafrost;

- Methods of controlling of natural and industrial gas hydrate and asphalt, gum and paraffin sedimentation;

- Complex analysis and monitoring of natural environment; 
- Analysis of hydrocarbon fluids at oil and gas fields development and operation.

\section{Conclusion}

Petroleum engineering education is fundamental for the development of the oil and gas industry in Russia and beyond. Our graduates have already taken up various posts with an impressive list of companies in the oil and gas employment market.

At present, 111 petroleum engineers have graduated from our Institute, 59 of them from full-time studies, 52 from part-time studies. The majority are employed in leading oil and gas enterprises: GAZPROM, SURGUTNEFTEGAZ, L U K O I L, S A K H A L I N E N E R G Y, SAKHATRANSNEFTEGAZ, LENSKGAZ, ALROSA GAS, IRELYAKHNEFT, and foreign oil and gas companies Total and Baker Hughes.

$30 \%$ of our graduates have the Master's Degree in Petroleum Engineering taken at Gubkin Russian State University of Oil and Gas.

By the end of 2015, a new building of the Institute will be put into operation with all the necessary facilities and modern laboratories. This will be another step in the development of oil and gas education in western Yakutia and

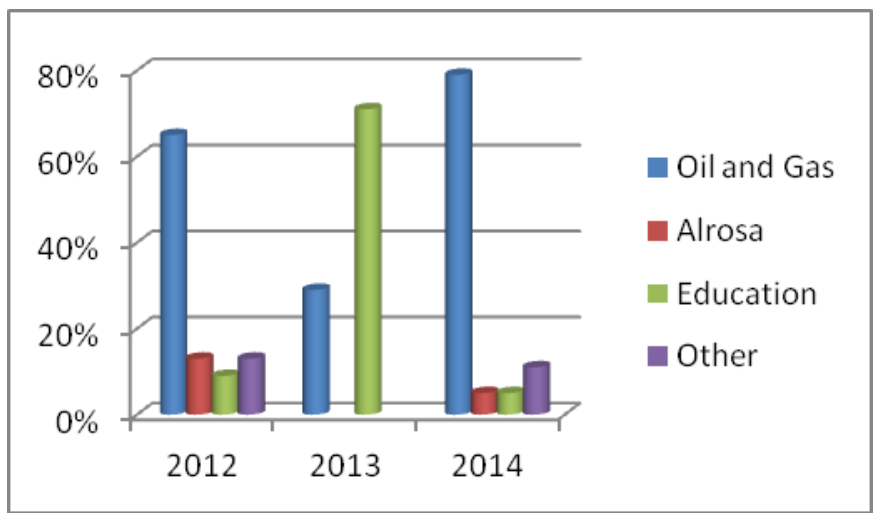

Fig. 3. Provides the information on annual employment of our graduates

consequently an important contribution to the sustained development of oil and gas extraction in the Sakha Republic, Russia.

\section{References}

1. Yakutia possesses 59 types of mineral and hydrocarbon crudes (2015, May 28). Information analytical portal SakhaNews [Online]. Available: http://www.1sn.ru/140291.html

2. The Republic of Sakha (2015, May 30). About the Republic. Official Site of The Republic of Sakha [Online]. Available: http://www.sakha.gov.ru/

3. Russia signs 30-year deal worth $\$ 400 \mathrm{bn}$ to deliver gas to China (2014, May 21). The Guardian [Online]. Available: http://www.theguardian.com/world/2014/may/21/russia-30-year-400bn-gas-deal-china

4. Goldman A.A., "Mirny Polytechnic Institute: Future is created in the present", Gorny Zhurnal, no. 1, pp. 6-9, 2014.

5. About us. Alrosa (2015, June 22). Alrosa [Online]. Available: http://eng.alrosa.ru/ 
6. Mirny Polytechnic Institute (branch) of Ammosov North-Eastern Federal University (2015, May 27). Official Site of Mirny Polytechnic Institute (branch) of Ammosov North-Eastern Federal University [Online]. Available: http://en.unimir-ysu.ru/

7. Zyryanov I.V., Dvoychenkova G. P., Kovalchuk O. Y., "Scientific Educational Centre of MPTI - the Platform of Higher Education Development in Western Yakutia", Gorny Zhurnal, no. 1, 2014.

\title{
Перспективы нефтегазового образования
}

в Политехническом институте (филиале)

ФГАОУ ВПО «Северо-Восточный федеральный университет

им. М.К. Аммосова» в г. Мирном

\author{
А.А. Гольдман \\ Мирный политехнический институт (филиал) \\ Северо-Восточного федерального университета (СВФУ) \\ им. М.К. Аммосова \\ Россия, 678170, Саха (Якутия), Мирный, ул. Тихонова, 5/1
}

\begin{abstract}
В статье рассматриваются актуальные вопросы нефтегазового образования в Мирнинском политехническом институте (филиале) ФГАОУ ВПО «Северо-Восточный федеральный университет им. М.К. Аммосова». Стремительное развитие нефтегазовой промылиленности в республике ознаменовало открытые направления подготовки «Нефтегазовое дело». Политехнический институт обладает необходимым кадровым потенииалом, материальнотехнической базой и удобным географическим положением для развития нефтегазового образования. Студенты нефтегазового отделения проходят практику на действуюших предприятиях по добыче нефти и газа и ведут научно-исследовательскую работу в тесной взаимосвязи с производством. Первые выпускники нефтегазового отделения успешно трудоустроены по специильности и продолжают свое обучение в магистратуре Российского государственного университета нефти и газа имени И.М. Губкина. Строится новое здание учебно-лабораторного корпуса с необходимым оборудованием и специализированными лабораториями для нефтегазового направления.
\end{abstract}

Ключевые слова: Мирнинский политехнический институт, промышленные предприятия, нефтегазовая промышленность, высшее образование.

Научная специальность: 13.00 .00 - педагогические науки. 